\title{
A Survey of the Cultural Policies of Berlin, Paris, Vienna, and Zagreb Regarding their Urban Peripheries
}

\author{
By Walter Rohn*
}

\begin{abstract}
Cultural facilities such as theatres, cinemas, galleries, exhibition spaces, music venues, and flexible multi-use locations are in a valuable position to stimulate the development of urban peripheries. However, there is a lot to be done to make things work. This paper looks at the cultural scenes in Berlin, Paris, Vienna and Zagreb in particular, the cultural facilities on the outskirts of these four metropolises and the respective municipalities' cultural policies for their urban fringes. The survey shows that there are fundamental differences in the four metropolises' cultural policies: Whereas Paris and Zagreb are fostering the cultural development of their outlying districts, Berlin and Vienna lag behind. Ironically, municipalities in more centralist states like Paris and Zagreb - when it comes to culture - are doing more for their peripheries than those in states with a federal structure, that is to say Berlin and Vienna.
\end{abstract}

Keywords: Cultural policy, European metropolises, Urban peripheries.

\section{Introduction}

Peripheries and fringes exist on different levels. In the 1970s and 80s, the global South was deemed "peripheral" (Senghaas 1972, 1974). Terms that distinguish between countries based on different levels of development have nowadays been largely disposed with (The World Bank 2016). There are, of course, also centres and margins within states. This paper focuses on peripheries within cities. Metropolises, cities and towns always consist of different parts. On the one hand, there are one or more centres and on the other hand, the outer parts (Florida 2013, Heineberg 2000, Metzger 2015). These outer parts are usually termed peripheries, outskirts or margins. Urban peripheries may therefore be defined as the parts of a city surrounding the city centre(s) or as the outer parts of a town.

In most cities, huge infrastructural disparities exist between the centres and margins, e.g. regarding institutions of higher education, medical care, public transport, car sharing and bicycle rental stations, sophisticated shopping facilities, banks, cash machines, etc. In the field of culture, disparities between centres and peripheries are starker still.

This paper looks at the cultural scenes in Berlin, Paris, Vienna and Zagreb in particular, the cultural facilities on the outskirts of the four metropolises and

\footnotetext{
* Senior Scientist at the Institute for Urban and Regional Studies at the Austrian Academy of Sciences in Vienna, Austria.
} 
the respective municipalities' cultural policies in favour of their urban fringes. This paper is the first time that research results on the four capitals have been published.

The paper begins by sketching the research project from which the information presented in this paper derives from. In the following part, portraits of Berlin, Paris, Vienna, and Zagreb and the cities' approaches to the outskirts is described and analysed. The next section offers a comparison of the cultural policies in the four metropolises. The paper finishes with some concluding remarks.

\section{Research Work}

Since the beginning of the $21^{\text {st }}$ century, a broad range of cultural facilities - such as theatres, cinemas, galleries, exhibition spaces, music venues, and flexible multi-use locations - have been established on the outskirts of European cities. The various players, venues, styles of art presentation, audiences and modes of financing differ widely depending on the city.

These cultural facilities mark the starting point of a mid-term research project carried out by the author at the Institute for Urban and Regional Studies at the Austrian Academy of Sciences in Vienna. Research on the project $\mathrm{New}$ Culture on the Outskirts of Cities, co-funded by Vienna's municipal office for culture, was completed in 2014.

The theoretical framework of the study refers to the work and concepts of Franco Bianchini and Lia Ghilardi (2004), Bruno Latour (2007), Kevin V. Mulcahy (2006), and Dorte Skot-Hansen (2005), with the study essentially divided into two parts. The first section focused on Vienna and Paris, with results presented in a book entitled New Culture on the Outskirts of Cities: Vienna and Paris (Rohn 2013); in the second part, research was conducted in Berlin and Zagreb.

The project's primary research questions were:

1. What are the basic characteristics of new cultural facilities on the outskirts of European cities?

2. In which ways do the venues contribute to a positive development of urban fringe areas?

3. How can a cultural policy in support of peripheral cultural facilities be designed?

In order to investigate developments in the four capitals, methods including field studies, participating observation and in-depth interviews with representatives from various cultural facilities, overall experts and political representatives were applied as research methods. In Berlin, Paris, Vienna and Zagreb more than 60 interviews were conducted, the largest number of which were in the Austrian capital. 
The selected case study area in Berlin was the district of Neukölln in the south of the city; in Paris, Ménilmontant to the east of the city; the districts of Ottakring (west), Döbling (north) and Floridsdorf (northeast) in Vienna; and in Zagreb the districts Novi Zagreb-istok and Novi Zagreb-zapad in the south of the Croatian capital. In total, the author spent nearly four months carrying out field research in Berlin, Paris and Zagreb.

Research questions two and three were basically addressed sed by conducting interviews with 13 experts in the fields of culture, urban development and city administration in Vienna. Regarding the cultural facilities' effects on development on the urban outskirts - the second research question - the experts expressed their overall opinion that cultural facilities are capable of stimulating the cultural, urban, economic and social development of urban fringe areas. Specifically, that the venues may contribute to the improvement of an area's cultural infrastructure, help to democratise culture, encourage urban development and have an impact on the improvement of living conditions. Furthermore, cultural facilities have the ability to stimulate the creation of jobs and the advancement of creative industries. Finally, cultural facilities are expected to foster the political participation of citizens, the integration of different sections of the population, the creation of a distinct identity of the outskirts and a stronger identification and sense of belonging for the population with the area they live in (see the following section).

To take full advantage of the cultural facilities' positive effects on urban development, it is necessary to design and implement a cultural policy in favour of the urban fringes. The basic requirements of such a strategy are:

- A strong commitment from the municipality towards the people living on the outskirts of the city.

- An adequate funding of cultural projects on the urban fringes.

- A combination of resources from the department of culture with financial means from other municipal branches, such as urban regeneration, housing, education, social affairs, etc. (see Bianchini and Ghilardi 2004).

- A transfer of financial resources (e.g. from high culture).

The following sections will show how the four European metropolises tackle this challenge.

\section{Berlin, Paris, Vienna, and Zagreb}

This section offers an overview of the cultural scenes and policies of the four European case study metropolises, with their different backgrounds and traditions (in the cities' alphabetical order). Berlin and Paris are the capital cities of large states, whereas Vienna and Zagreb represent smaller ones. Berlin and Vienna are capitals of states within a federal system, whereas Paris and Zagreb are representatives of a more centralist approach. Of the four cities, Berlin has the largest population and Zagreb the smallest (see Table 1). In 
regards to size in terms of area, Berlin is on the largest and Paris the smallest. Paris has the highest population density and Zagreb the lowest. The national languages differ, so too does the different countries' history of membership in the European Union; Berlin and Paris are capitals of states with a very long membership to the European Union; Zagreb is in the most recent member state.

Table 1. Basic Figures for Berlin, Paris, Vienna, and Zagreb

\begin{tabular}{|l|c|c|c|c|}
\hline Indicator & Berlin & Paris & Vienna & Zagreb \\
\hline Number of inhabitants & $3,520,031$ & $2,229,621$ & $1,840,573$ & 790,017 \\
\hline Area $\left(\mathrm{km}^{2}\right)$ & 891.7 & 105.4 & 414.9 & 641.4 \\
\hline $\begin{array}{l}\text { Population density (inhabitants per } \\
\mathrm{km}^{2}\end{array}$ & $3,947.6$ & $21,153.9$ & $4,436.2$ & $1,231.7$ \\
\hline Number of districts & 12 & 20 & 23 & 17 \\
\hline
\end{tabular}

Note: Data for Berlin as of December 2015, Paris of January 2013, Vienna of January 2016 and Zagreb of March 2011 (most recent available data).

Sources: Wikipedia 2016a, 2016b, 2016c, 2016d.

The first city presented here is the German capital of Berlin. According to its status as a federal state, Berlin is officially named Land Berlin. The city is governed by the mayor, the Senate and the Chamber of Deputies. Long-time mayor, Klaus Wowereit, resigned in December 2014, with Michael Müller taking over as his successor. Tim Renner succeeded André Schmitz in the post of the Berlin secretary of state for cultural affairs (Wikipedia 2016a, Schaper 2014).

In December 2015, there were 3,520,031 inhabitants in Berlin on 891.7 $\mathrm{km}^{2}$, representing a population density of 3,947.6 inhabitants per square kilometre. Berlin is divided into twelve districts. With the exception of Charlottenburg-Willmersdorf, Mitte and Friedrichshain-Kreuzberg, all districts extend to the border of the city. The central part of the city lies within the socalled S-Bahnring (fast train circle). Due to a large deficit, Berlin is currently in a tight financial situation (Rohn 2014, Wikipedia 2016a).

The structure of funding for arts and culture in Berlin is quite complicated and difficult to gain an overview of. The method of including the cultural money given by the state into its bookkeeping for cultural funding, is novel. According to the relevant documents from the Berlin municipality (see below), the major sponsors of arts and culture in the German capital are:

1. The Federal Republic of Germany via direct funding of major cultural institutions and special funds (inter alia culture fund for the capital).

2. The City of Berlin (the Senate) with its' funding of important cultural institutions and programmes.

3. The twelve Berlin districts with their funding of local cultural facilities.

According to the most recent available figures (for 2010), these three bodies provided a total of $€ 845 \mathrm{~m}$ for arts and culture in Berlin. Of this, $40.2 \%$ came from the Federal Republic of Germany, $45.6 \%$ from the Senate and $14.2 \%$ from the districts. Funds for construction and maintenance works are 
not included in this figure (Der Regierende Bürgermeister von Berlin Senatskanzlei Kulturelle Angelegenheiten 2011: 18).

In terms of cultural spending: The Senate spends $45.6 \%$ of the abovementioned sum $(€ 385 \mathrm{~m})$ immediately on what may be considered the direct cultural budget from the Senate. The direct budget is divided into institutional funding, which comprises approximately $95 \%$ of the immediate budget, and project funding. Berlin's districts distribute a certain cultural budget in a relatively autonomous way. As this money also comes from the central administration, it may be considered an indirect budget from the Senate (Der Regierende Bürgermeister von Berlin - Senatskanzlei Kulturelle Angelegenheiten 2011: 8).

The Federal Republic of Germany (respectively the Representative of the Federal Government for Culture and Media) in Berlin sponsors - amongst other things - specific foundations and memorials, the Berlinale international film festival and Berliner Theatertreffen, a line-up of the year's best theatre productions in German-speaking countries. Together with the Berlin municipality and other federal states, the Federal Republic sponsors the state museums in Berlin on the Museumsinsel and in other locations (Der Regierende Bürgermeister von Berlin - Senatskanzlei Kulturelle Angelegenheiten 2011: 18).

The major cultural institutions in Berlin are financed by the city, that is to say, the Senate. These are the State, German and Comical Opera and their orchestras as well as the Berlin Philharmonic. The most prestigious theatres are the German Theatre, People's Stage (Volksbühne), the Berlin Ensemble, Show Stage (Schaubühne) and Hebbel at the Waterside. Furthermore, the municipality sponsors institutions and festivals for literature, museums, special memorials, and public libraries like Central and County Library as well as many other institutions. As indicated above, these facilities are financed under the rubric of institutional funding. It comes as no surprise that the majority of Berlin's most important cultural institutions are situated in the city centre (Der Regierende Bürgermeister von Berlin - Senatskanzlei Kulturelle Angelegenheiten 2011: 14ff., Der Regierende Bürgermeister von Berlin Senatskanzlei Kulturelle Angelegenheiten 2015).

As expressed by Renate Rolke, a leading representative of the municipality's department for culture, the city administration is oriented towards the cultural aims of the city as a whole, not towards those of specific parts of the city (R. Rolke, personal communication, April 11, 2013).

An effective measure to support artists in the German capital is the Berliner Atelierprogramm. This programme is financed through project funding, supporting approximately 800 subsidised artist studios and apartments provided by the city. Additionally, there are rehearsal spaces for theatre, dance and music (R. Rolke, personal communication, April 11, 2013).

The funding of local cultural institutions, programmes and activities is the responsibility of Berlin's 12 districts. The districts' cultural agenda is basically made up of local libraries and museums, music schools and art schools for young people as well as adult education. In addition to their regular cultural 
budget, the districts also receive money from a special cultural fund for districts and another fund for cultural education (B. Müller personal communication, April 11, 2013, R. Rolke, personal communication, April 11, 2013).

Figure 1. Gallery at Saalbau (Neukölln/Berlin)

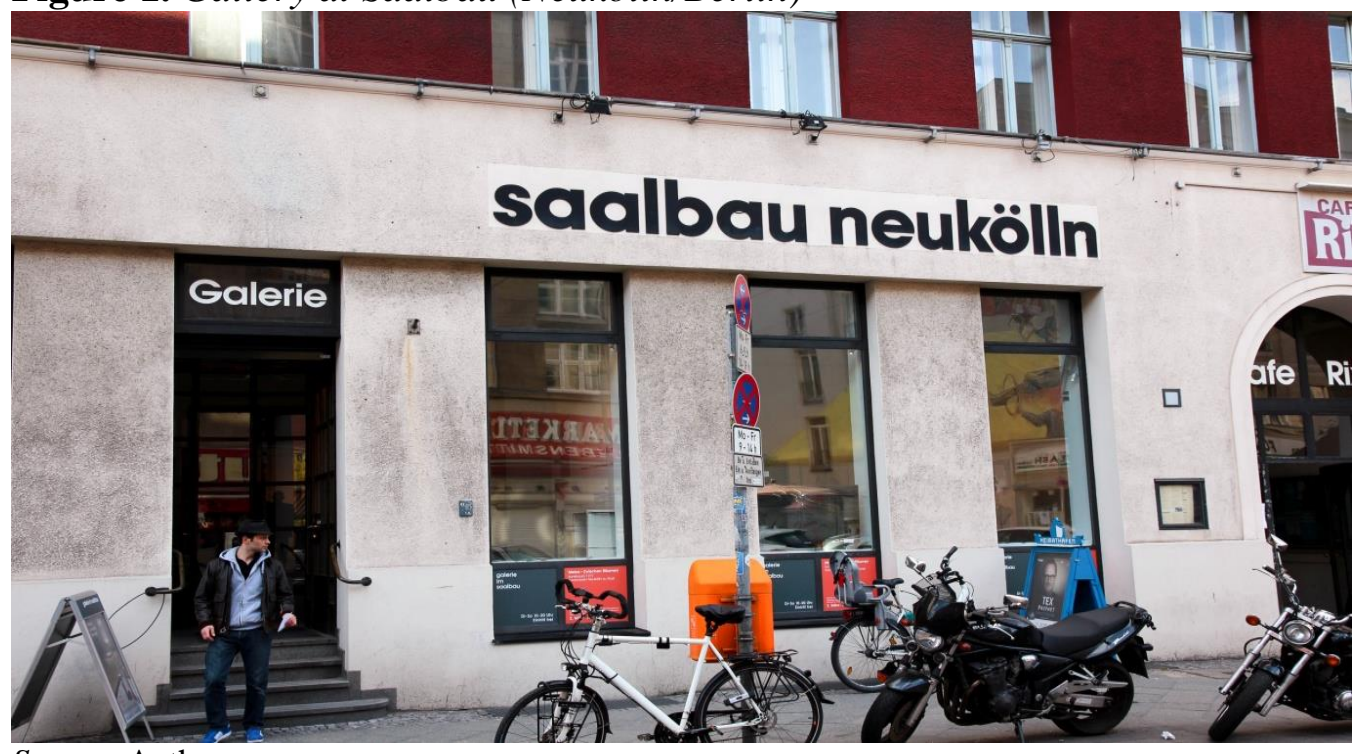

Source: Author.

Special funds like the Lottery Fund as well as the private Mercator and Bosch foundations exist from which local cultural facilities can draw additional financial resources. Money distributed by the employment office gives cultural (and other) facilities the opportunity to pay unemployed people small sums. This so-called 'second labour market' allows cultural facilities access to additional staff to get necessary work done (R. Kramer, personal communication, April 10, 2013, R. Rolke, personal communication, April 11, 2013).

In general, cultural funding by the Senate and the districts is restricted to cultural purposes. Local territorial development, especially for disadvantaged urban areas, is funded via special funds. These funds are Aktionsräume plus (financed by the municipality's department for urban development) and Quartiersmanagement (resources by the Federal Government). Aktionsräume $^{\text {plus }}$ is operated in cooperation with EU-funds (B. Müller personal communication, April 11, 2013, R. Rolke, personal communication, April 11, 2013).

To summarise, there is a clear distinction between properly sponsored large cultural institutions like operas, theatres, museums, etc. in the centre of Berlin and the comparatively poorly financed smaller cultural facilities outside the S-Bahnring. Activists and directors of cultural facilities in the peripheral areas of Berlin have to write many project proposals to public and private donors to make ends meet. In autumn 2016 - after this paper's completion elections for the Berlin Chamber of Deputies will be held. 
Figure 2. Stage Home Port (Neukölln/Berlin)

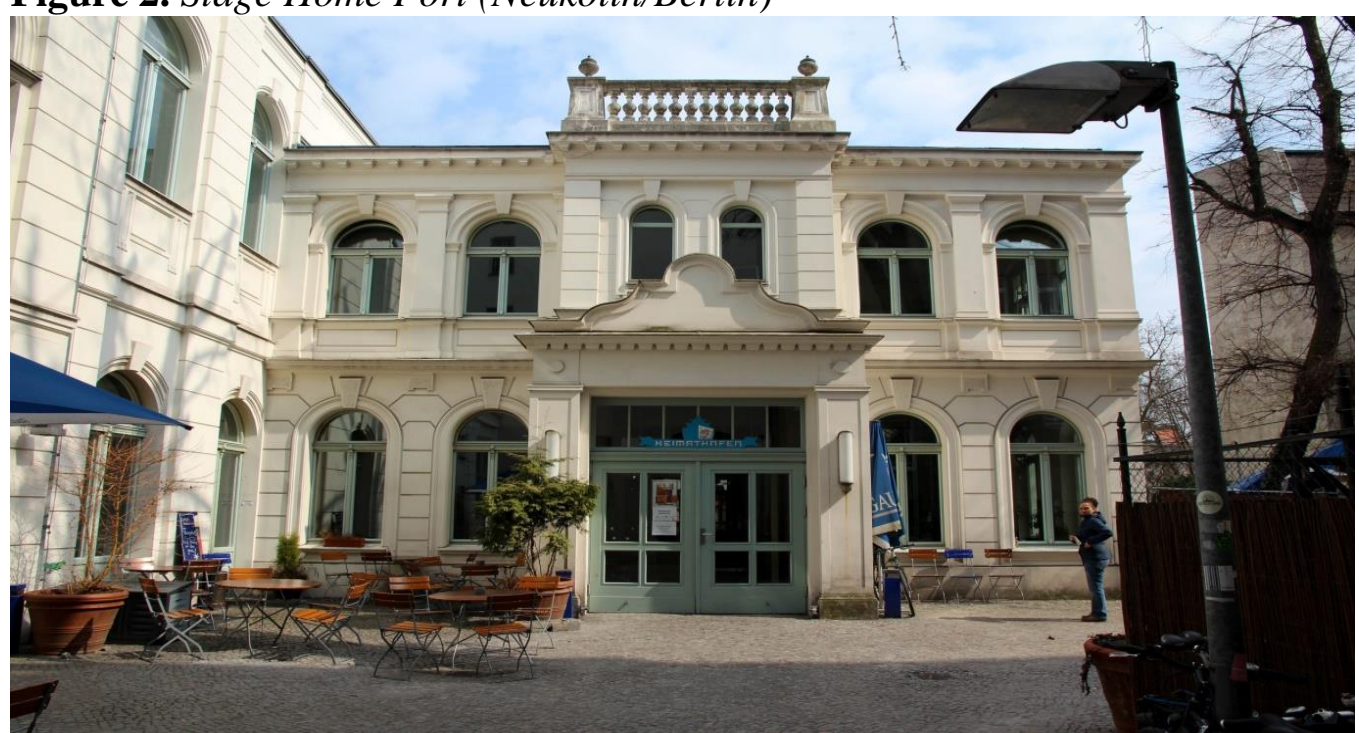

Source: Author.

With an area of $105.4 \mathrm{~km}^{2}$, Paris is the smallest of the four metropolises. With its 2,229,621 inhabitants (as of January 2013) the French capital represents the most densely populated city in Europe, with an average of 21,153.9 people per $\mathrm{km}^{2}$ in Paris. Due to the sheer density of buildings, institutions, facilities, etc. it is easy to get the impression that Paris is a large city. The City of Paris comprises 20 districts, the arrondissements 12 to 20 are (more or less) classified as the town's peripheral areas (Mairie de Paris 2012a, Pavillon de l'Arsenal 2009, Wikipedia 2016b).

As in every capital city, in Paris there are at least two important players in the field of culture. The French Ministry of Culture and Communication amongst others - funds the two opera houses, Garnier and Bastille, the theatres Comédie-Française, Chaillot, La Colline and Odeon, the museums of the Centre Pompidou, the Louvre, Guimet and d'Orsay (J.-F. de Canchy, personal communication, September 28, 2007).

Other large cultural institutions run by the City of Paris include the Forum des Images film archive, the House of European photography, the Parisian Museum of Modern Art, Théâtre du Châtelet (for opera and music theatre) as well as the Dance Theatre and the City Theatre. In total, the City of Paris maintains 21 museums, 19 theatre houses and concert halls, 57 general and 9 specialist libraries, 19 music schools, 21 artist's workshops, 85 churches and the bridges within the city. Additionally, the city co-sponsors the Paris Orchestra, Théatre de la Bastille, the association of private theatres and some art house cinemas (Mairie de Paris 2012b, 2012c).

With the Grands Travaux (great works) of the mid-1980s, President Mitterand started a large-scale decentralisation of major state cultural institutions in Paris. Examples of this policy are the Bastille Opera (in the $12^{\text {th }}$ district), the National Library $\left(13^{\text {th }}\right)$ and the Science Museum at la Villette $\left(19^{\text {th }}\right)$. Also in the mid-1980s the Théâtre de la Colline $\left(20^{\text {th }}\right)$ was inaugurated. Later on came, for example, the French cinema museum in the $12^{\text {th }}$ and the 
new concert hall Philharmonie de Paris at La Villette in the $19^{\text {th }}$ district (Cinémathèque française 2016, Connaissance des Arts 1989, Philharmonie de Paris 2016, Rohn 2013).

The cultural policy of the City of Paris is determined by the mayor, the councillor for culture, and the city council and administered by the Directorate for Cultural Affairs (DAC). In 2001, Bertrand Delanoë became mayor of Paris (remaining in office until 2014) and Christophe Girard was appointed councillor for culture. The two main aims of Delanoë's and Girard's cultural strategy were a doubling of the city's budget for culture and a more equal distribution of the city's cultural resources among the districts of the French capital (C. Girard, personal communication September, 27, 2007, Wikipedia 2016e).

The Paris municipality improved access to culture, gave residents free entrance to the permanent collections of the city's museums, modernised the libraries, carried out a reform of the music schools and gave strong support to local cultural initiatives including community organisations, street art, small theatres, short films, dance and music companies (C. Girard, personal communication, September 27, 2007).

Starting in 2001, the Paris municipality developed a broad range of new cultural facilities on the margins of the city, including:

- City of Fashion and Design in the $13^{\text {th }}$ district.

- Music centre Fleury Goutte d'Or - Barbara.

- Interactive theatre Le Grand Parquet.

- Site Trois Baudets for chanson music.

- Institute for Islamic Culture with two sites (all 18th) and

- Fine arts centre Centquatre in the 19th district (C. Girard, personal communication, September 27, 2007, Institut des Cultures d'Islam 2016).

The Paris municipality also built large médiathèques in peripheral districts and runs cultural centres in the $20^{\text {th }}$ district Ménilmontant in the east and other districts. Furthermore, the municipality provides the districts with a sufficient amount of money for their own cultural activities. Accordingly, Parisian districts are in a position to spend one euro per inhabitant on local cultural activities. In his position as councillor for culture, Christophe Girard created the White Night which stretches out into the peripheral parts of Paris too (personal communication, September 27, 2007). 
Figure 3. District Cultural Centre Carré de Baudouin (Ménilmontant/Paris)

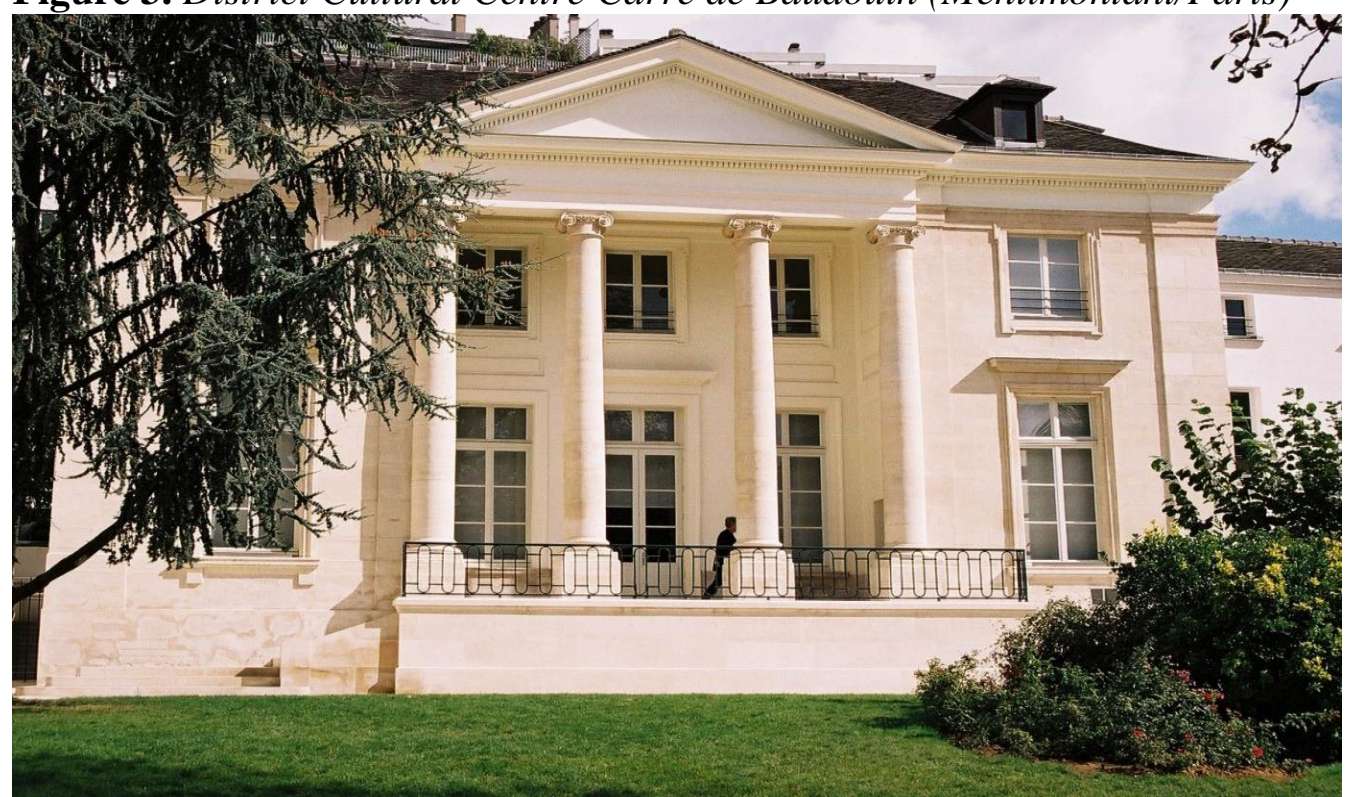

Source: Author.

Furthermore, the Paris municipality set up the programmes Charter of Cultural Cooperation (2009) and Paris, City of Culture and Creation (2011) which offer strong support to cultural activities on the margins of the city (Mairie de Paris 2009, 2011, 2013).

Figure 4. Media Centre Marguerite Duras (Ménilmontant/Paris)

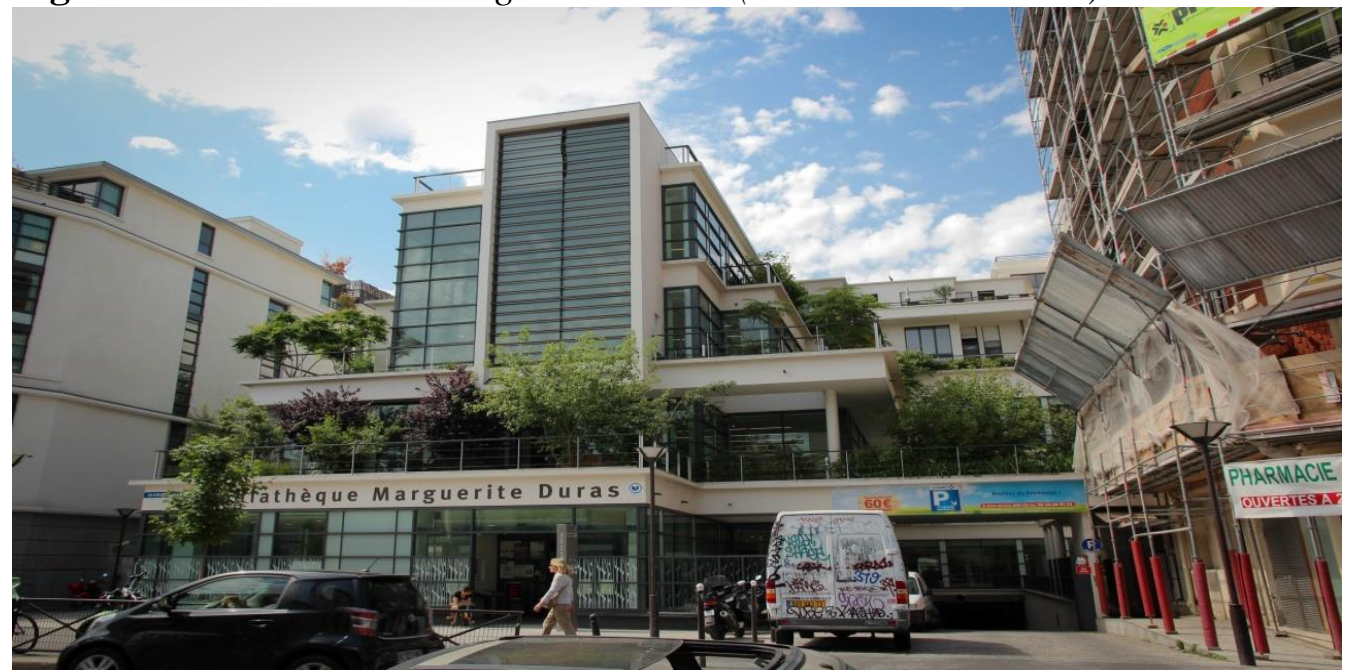

Source: Author.

In 2016, the Paris municipality devoted $€ 376.7 \mathrm{~m}$ to culture, of which $€ 311.7 \mathrm{~m}$ will be spent on current operations and $€ 65 \mathrm{~m}$ on investments. Compared to 2011, the cultural budget of Paris has, once again, more than doubled (Mairie de Paris 2012c, 2016). The financial means of the Paris municipality invested in arts and culture are being supplemented by those of 
other territorial authorities like the Regional Board of Cultural Affairs, Île-deFrance.

Christophe Girard resigned from his post as councillor for culture in 2012 and became mayor of Paris' $4^{\text {th }}$ district, in French politics an advancement. Bruno Juillard became the new councillor for culture. In 2014, Anne Hidalgo won the elections in Paris and became Delanoë's successor as mayor of Paris (Gréco 2012, Wikipedia 2016f).

By way of summary, it can be said that the Paris municipality has shown a strong commitment towards the city's peripheral areas by establishing a broad range of new cultural institutions on the margins of Paris and providing the districts with sufficient financial resources for cultural purposes. In contrast to Berlin, the municipality of Paris definitively uses cultural resources to advance spatial priorities.

The third case study city is Vienna, the capital of Austria. Vienna has $1,840,573$ residents living in an area of $414.9 \mathrm{~km}^{2}$. The population density amounts to $4,436.2$ persons per $\mathrm{km}^{2}$ (as of January 2016). In terms of population and area, Vienna is the third largest city of the four chosen capitals. The outer parts of Vienna are comprised of the districts outside the Gürtel, a circular road (i.e. the districts 10 to 20 and 23 on the right bank of the Danube), and two districts on the left bank (districts 21 and 22) which together house more than three quarters of Vienna's population (Magistrat der Stadt Wien 2015, Wikipedia 2016c).

With some important cultural institutions supported by the state and some funded by the City of Vienna, the Austrian capital also has a double structure. The large theatres (Burgtheater and Akademietheater) and the opera houses (Staatsoper and Volksoper) are maintained by the state. State museums in Vienna include the Albertina, the Belvedere, the Museum of $21^{\text {st }}$ Century Art, the Kunsthistorisches, the Natural History Museum, the World Museum, the Theatre Museum, the Museum of Applied Arts, the Leopold Museum and MUMOK at Museumsquartier as well as Museum of Technology. With the exception of the Museum of Technology, all of these institutions are located in the inner districts (Bundeskanzleramt 2016, Bundestheater 2016).

The City of Vienna is responsible of the following large and medium-sized theatres, all of which are theatres in (more or less) the classical form: Volkstheater, Theater in der Josefstadt, Schauspielhaus, Theater in der Gumpendorfer Straße and Rabenhoftheater. United Stages Vienna stage operas at the Theater an der Wien and the Kammeroper as well as musicals at the Renaissancetheater and the Ronacher. Other important cultural institutions are the Kunsthalle and the Centre for Architecture at Museumsquartier, the Vienna City Museum and other local museums as well as the Film Museum (cofinanced with the state) and the municipal cinema, Stadtkino. It almost goes without saying that all these institutions are located in the inner districts of Vienna.

In addition to these locations, the city funds a number of large and medium-sized festivals like the Wiener Festwochen (for theatre and opera), Impulstanz (dance), O-Töne and Literatur im Herbst (both literature), the 
Viennale (for film), Eyes On (photography) as well as Wien Modern and Popfest Wien (both music). Of these festivals, only the Wiener Festwochen has productions in locations outside of the city centre (Geschäftsgruppe Kultur und Wissenschaft 2015, Vereinigte Bühnen Wien 2016).

Decisions regarding culture are made at various levels by Michael Häupl, Vienna's mayor, and Andreas Mailath-Pokorny, the city councillor for culture, the municipal council and the city's commission for culture. According to its report on art and culture, in 2014 Vienna spent $€ 227.5 \mathrm{~m}$ on culture (Geschäftsgruppe Kultur und Wissenschaft 2015). In terms of the budget of the City of Vienna, the sum is higher because of some other budgetary items indirectly related to culture.

The bulk of cultural financing by the city of Vienna goes to institutions, festivals and other related activities in the inner districts. Marie Ringler, the former spokesperson for the Green Party Vienna in matters of culture, estimated the proportion of funds spent in the city's central districts to be about $80 \%$ (M. Ringler, personal communication, September 17, 2009). There are but a few big and medium-sized cultural institutions on the fringes of Vienna that receive direct funding from the municipality. In addition to that, the 23 districts have cultural budgets of varying sums of money at their disposal.

The outskirts of Vienna have more recently come to house some bigger cultural facilities (in the broadest sense) such as

- Brotfabrik, established by the private company Loft City GmbH \& Co. $\mathrm{KG}$, was officially inaugurated in 2015 . The former bread factory is a venue in the $10^{\text {th }}$ district of Vienna that houses art galleries like Hilger Brotkunsthalle, Hilger Next, Ostlicht and Anzenberger Gallery, as well as some social and charitable ventures by organisations such as Caritas, like Atelier 10 and Magdas Kantine, along with other facilities.

- Education Centre Simmering $\left(11^{\text {th }}\right)$ was established in 2011 by the municipality of Vienna and houses an adult education centre, a branch of the public library and a music school.

- Despite its name the Bank-Austria-Halle is a public concert hall in the basement of the Gasometer housing estate (all $11^{\text {th }}$ ).

- The forerunner of Werk X (Factory X) was founded in the late 1990s by Hubsi Kramar and other artists at the former cable factory Kabelwerk $\left(12^{\text {th }}\right)$. At the beginning of this century, a new theatre building was built for Palais Kabelwerk. Following refurbishment in 2014, the public venue was reopened under the name Werk $\mathrm{X}$ and it now has two spaces for avant-garde theatre and DiverCityLab which is dedicated to postmigrant theatre. 
Figure 5. Art Centre Bread Factory (Favoriten/Vienna)

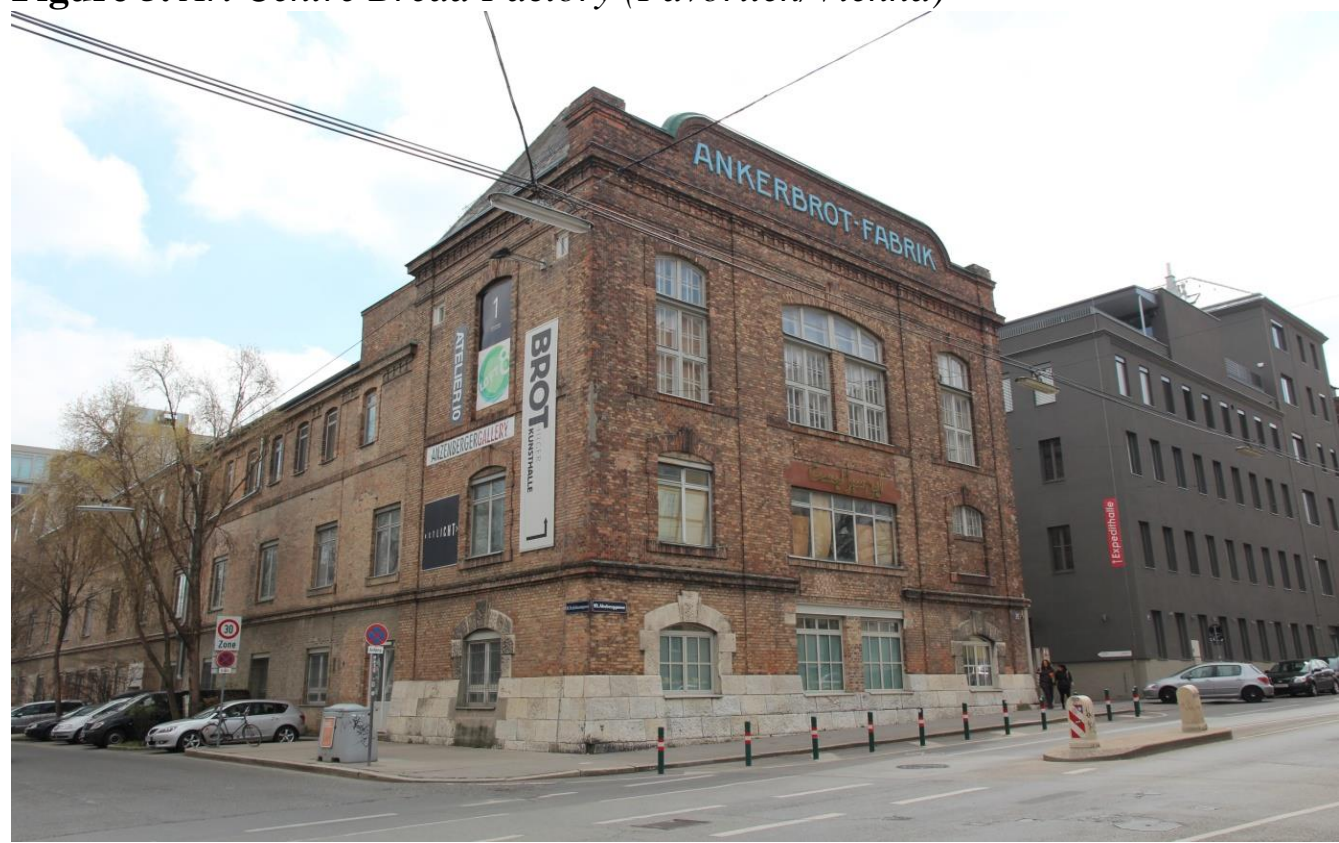

Source: Author.

Figure 6. Theatre Factory X (Meidling/Vienna)

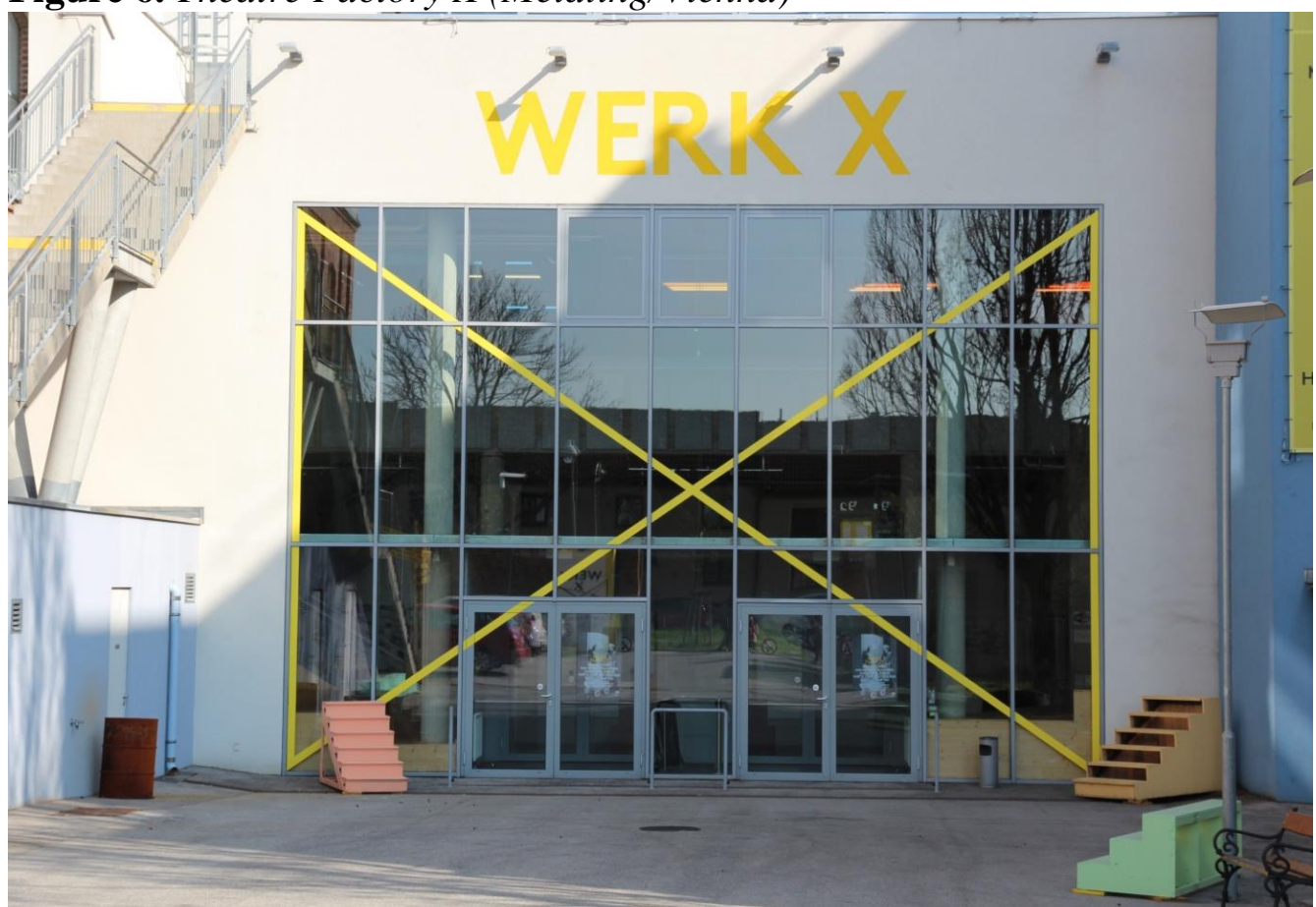

Source: Author.

- The Central City Library at Urban-Loritz-Platz, at the border of the $7^{\text {th }}$ and the $15^{\text {th }}$ district, was opened in 2003 and houses the headquarters and largest branch of the public libraries in Vienna. 
- Halle $F$ of Wiener Stadthalle $\left(15^{\text {th }}\right)$ is a medium-sized public concert hall inaugurated in 2006.

- The art-fair Soho in Ottakring was established in 1999 by Ula Schneider and other artists in the area of Yppenplatz and Brunnenmarkt $\left(16^{\text {th }}\right)$. In 2013, the now publicly subsided venture moved further west into the district at the public housing estate of Sandleitenhof.

- Gloria theatre $\left(21^{\text {st }}\right)$ once was a private multiplex cinema. In 2001, Gerald Pichowetz, the director of a former small theatre nearby, took over the site and converted it into a theatre with three halls. Today the location for boulevard theatre gets a stable subsidy from the Vienna municipality for its activities.

- Finally, there are some private multiplex cinemas in peripheral parts of Vienna, such as the Lugner Kino City in the $15^{\text {th }}$, UCI Kinowelt Millenium City in the $20^{\text {th }}$, and Cineplexx Donauplex in the $22^{\text {nd }}$ district (Büchereien Wien 2016, Rohn 2013, 2015, Soho in Ottakring n.d., Stadt Wien 2016).

This list is a summary of the most important recent and larger scale cultural facilities on the outskirts of Vienna established by either the municipality, the civil society or the private sector. Nevertheless, it must be noted that the majority of cultural facilities on the outskirts are based on initiatives by artists and local residents, primarily of a smaller or medium scope and permanently underfinanced.

In addition to these permanent facilities on the fringes, there are some temporary projects and festivals. The biggest event on the periphery of Vienna is the free music festival on the island between the two branches of the river Danube that takes place each June. Some other festivals like the International Accordion Festival, the Klezmore Festival, Crime Fiction Night, the stroll around galleries Q202, Vienna Blues Spring, the touring open air cinema Volxkino and Wean Hean, the festival of Viennese folk music, also stretch out into the urban periphery (Rohn 2013).

It is important to note that over centuries Vienna has always been a very centralist city. As the listing of major cultural institutions financed by the state or the municipality shows, this - more or less - holds true still today. Only more recently has the situation begun to improve. The Vienna Design Week 2015 , for example, chose the $10^{\text {th }}$ district as the focus district and the festival's headquarters were located at Bread Factory (Vienna Design Week 2016). In spring 2016, Vienna's councillor for culture launched an initiative regarding local cultural activities. However, the Vienna municipality has yet to develop a distinct cultural strategy for its outskirt areas to correct the depicted imbalance.

Finally, yet importantly, the Croatian capital Zagreb. Covering an area of $641.4 \mathrm{~km}^{2}$, Zagreb has 790,017 inhabitants (as of March 2011). This results in a population density of $1,231.7$ inhabitants per $\mathrm{km}^{2}$. The city itself is made up of 17 districts, eight of which can be classified as urban periphery. These are Sesvete und Gornja Dubrava (Upper-Dubrava) in the east, Podsljeme in the north, Podsuset-Vrapče and Stenjevec in the west as well as Novi Zagreb-istok 
(New Zagreb-East), Novi Zagreb-zapad (New Zagreb-West) and Brezovica in the south. Zagreb has a very slim structure of top political representatives consisting of the mayor and two deputy mayors. In 2013, Milan Bandić was reelected as mayor. As one of the deputy mayors, Vesna Kusin is responsible for social activities and culture. Zagreb's municipal council is responsible for general decisions concerning the city (Grad Zagreb 2016, Rohn 2014, Trsat Polo d.o.o. n.d., Wikipedia 2016d, 2016g, V. Šimić Jajčinović, personal communication, June 12, 2014).

The Croatian state, that is to say the Ministry for Culture, is not as deeply involved in cultural institutions in Zagreb as we have seen in other cities. The state runs a broad range of national museums in Zagreb such as the Architectural Museum, the Museum of Naive Art, Museum of Croatian History and the School Museum. In partnership with the City of Zagreb, the state sponsors the Croatian National Theatre, the gallery Klovićevi Dvori and other facilities along with some festivals. The Ministry of Culture has also paid 50\% of the building costs for the new Museum of Contemporary Art Zagreb.

The bulk of cultural institutions, facilities and festivals in Zagreb are run by the city through its Municipal Department for Education, Culture and Sports. In 2013, Zagreb spent $€ 67 \mathrm{~m}-6.7 \%$ of its communal budget - on culture. This includes building and maintenance costs as well as salaries. The City of Zagreb owns and finances 36 cultural institutions, among them ten museums, seven theatres, three concert halls, several art-house cinemas, the municipal library as well as festivals and special programmes (V. Mihalić, personal communication June 12, 2014, V. Šimić Jajčinović, personal communication, June 12, 2014).

Among the most important cultural institutions and facilities in the city are the Zagreb City Museum, the Modern Gallery and the Museum of Contemporary Art Zagreb, theatres like the Zagreb Youth theatre, Communal Drama Theatre Gavella, Communal Comedy Theatre Zagreb and Satirical Theatre Kerempuh. Furthermore, the city funds the concert hall Vatroslav Lisinski and that of the Croatian music association, art house cinemas such as Europa, Tuškanac and Gric as well as the Zagreb Dance Centre and Pogon, the Zagreb centre for independent culture and youth. With the exception of the Museum of Contemporary Art Zagreb, all of the above-mentioned institutions are located in the city centre. In addition to these facilities, Zagreb hosts many festivals for music, theatre, dance, street art, cinema etc. (V. Mihalić, personal communication, June 12, 2014, V. Šimić Jajčinović, personal communication, June 12, 2014, Zagreb Tourist Board 2016).

Besides the cultural institutions in the city centre, Zagreb financially supports organisations in the more peripheral districts. Zagreb's flagship project in this respect is the huge Museum of Contemporary Art in New Zagreb, to the south of the city. The museum's forerunner, the Municipal Gallery for Contemporary Art, long had its seat in various buildings in the city centre. As the space grew too tight for the exhibitions and the collection, a relocation of the museum and various possible sites was intensively discussed. Based on a competition for the site in New Zagreb launched in 1999, the 
municipality decided to build the huge new museum. The new museum, designed by the Croatian architect Igor Franjić, was strategically placed at the crossroads of the north-south-axis Većeslava Holjevca Road and the important east-west-conjunction Dubrovnik Road.

The Museum of Contemporary Art Zagreb opened in December 2009 and all in all comprises $15,000 \mathrm{~m}^{2}$ over three levels. As indicated above, the building costs of the Museum of Contemporary Art Zagreb have been shared between the state and the City of Zagreb; the Zagreb municipality pays the operating costs. As Snježana Pintarić, the director of the MCAZ, indicates, the museum owns and presents works of contemporary art from Croatia, the successor states of former Yugoslavia and other areas. Among those are works of internationally renowned artists like Getulio Alviani, François Morellet, Rafael Soto and Victor Vasarely. In addition to its function as a museum, the institution works as a local cultural centre. Furthermore, the Museum of Contemporary Art Zagreb cooperates with cultural institutions internationally, like Kunsthaus Graz or Kunsthalle Wien (S. Pintarić, personal communication, June 10, 2014).

Figure 7. Museum of Contemporary Art Zagreb (Novi Zagreb-istok/Zagreb)

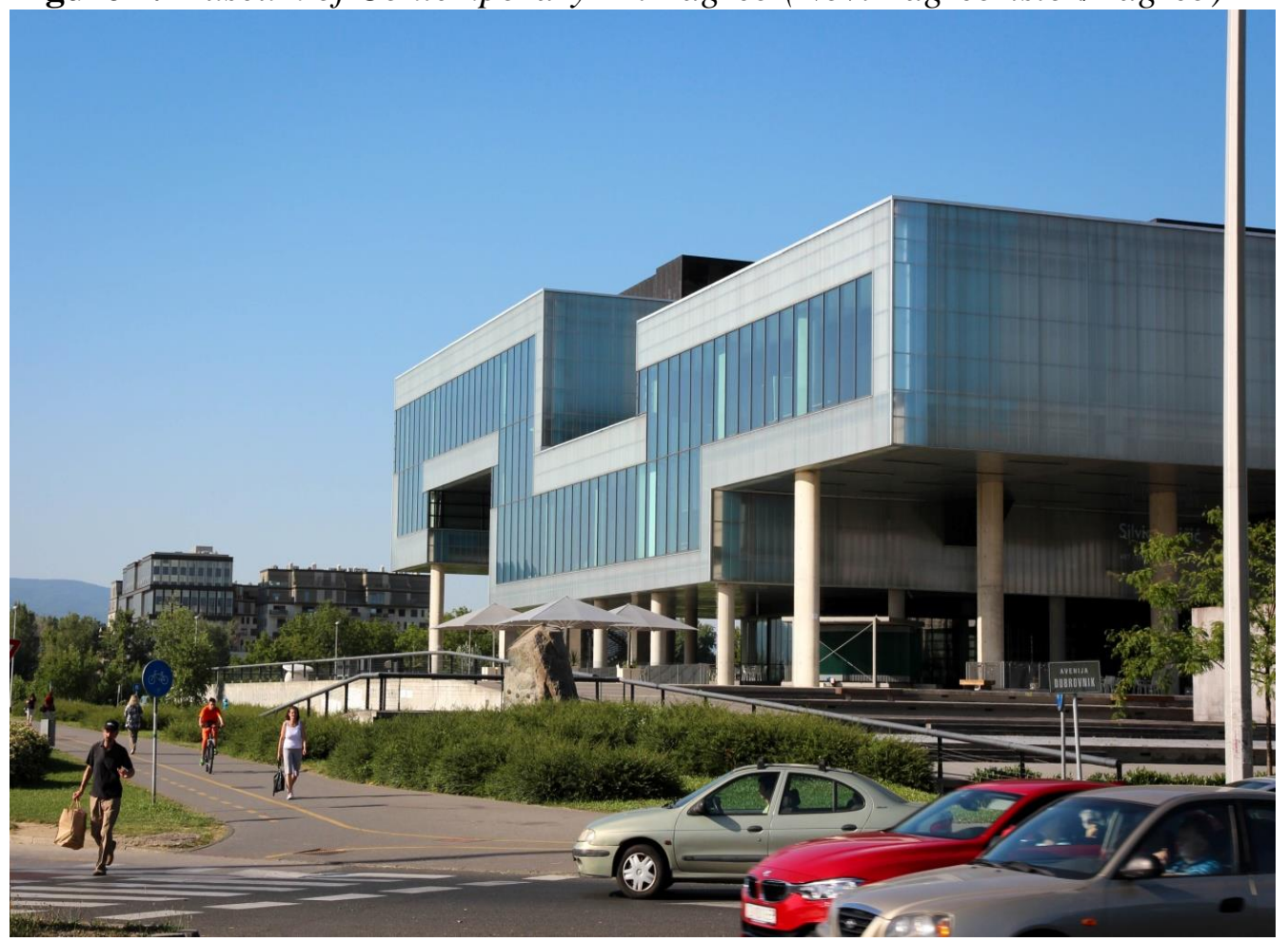

Source: Author.

Apart from the Museum of Contemporary Art Zagreb, New Zagreb is also home to some other cultural facilities such as Cinestar Novi Zagreb, Cinestar Arena IMAX, two local cultural centres and the sports facility Arena Centre which also hosts large concerts (Rohn 2014, Zagreb Tourist Board 2016). 
The cultural centres in the districts represent a second strong point of local cultural activities in Zagreb. The City of Zagreb has 13 of these local hubs. There are three different types: Socio-cultural centres, centres specialising in art education and those that focus on adult education. Three of the 13 cultural centres are located in the city centre and four in semi-peripheral areas and six centres are actually located on the outskirts. Subject to funding proposals, the cultural centres get sufficient money from the municipality for their cultural programmes and projects. In addition, the municipality pays fixed costs like operating costs, maintenance of the buildings and salaries. Quite often, there are theatres, art galleries and inclusive facilities for unemployed people, senior citizens, and people with disabilities associated to the centres. The cultural centres are closely linked to the people living in the respective neighbourhood. In general, the centres offer presentations and events in the fields of theatre, dance, music, film and fine arts as well as special courses for art education and language training. One such hub is Cultural Centre Trešnjevka (Centrikulture 2016, L. Perišić, personal communication, June 13, 2014).

Figure 8. District Cultural Centre Trešnjevka (Trešnjevka-Sjever/Zagreb)

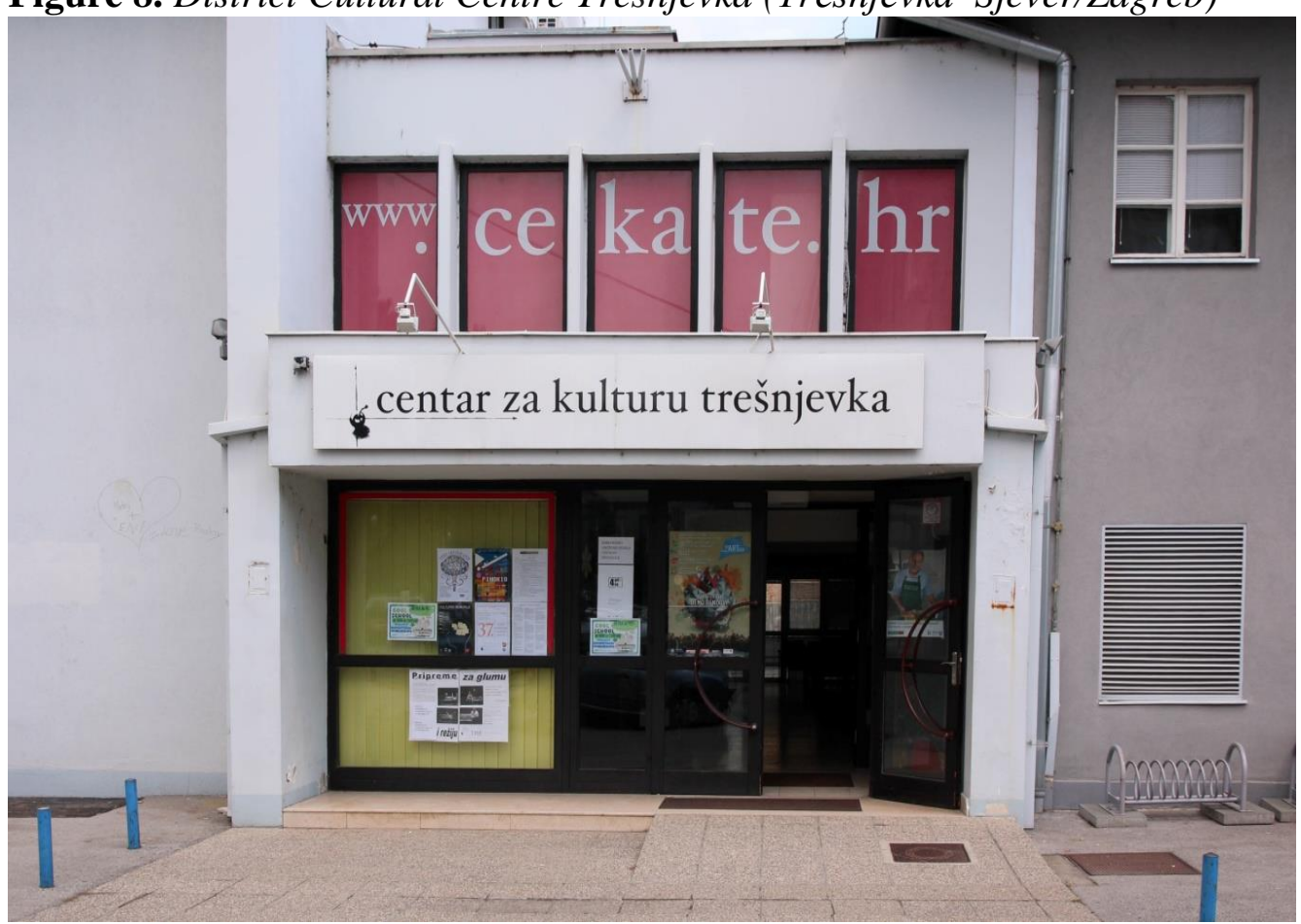

Source: Author.

An interesting example of urban regeneration in Zagreb is Akupunktura grada. Translating as 'City Acupuncture', the project is carried out by the Office for Strategic Planning and Development of the Zagreb municipality in cooperation with the Association of Architects. Small interventions like repainting urban furniture, putting up chairs or refurbishing a children's playground aim to improve the quality of life in various peripheral districts ( $\mathrm{J}$. Veselić Bruvo, personal communication, June 12, 2014). 
As shown above, the Zagreb municipality built and finances many cultural facilities on the fringes of the city, with the structure of Zagreb's cultural financing meaning that the municipality builds, manages and sponsors most facilities directly. The districts only manage small cultural budgets or no budgets at all. In the course of its Cultural Strategy for the years 2014-20, the Zagreb municipality aims to further improve cultural facilities in the urban periphery (V. Šimić Jajčinović, personal communication, June 12, 2014).

In coming back to the second research question (raised in the previous section) regarding the cultural facilities' positive effects on outskirts development, the following can be recorded. The experts consulted attributed positive effects in the fields of culture, urban development, economy and social affairs to cultural activities on the urban fringes. To definitively measure these outcomes would be a very time-consuming and costly approach. Therefore, the most feasible method is to observe the developments and changes occurring in specific outskirt areas.

The case study district Neukölln in the south of Berlin is characterised by a high percentage of inhabitants of foreign descent and is not one of the most attractive living areas in Berlin. The district houses several cultural facilities and institutions, some of them established in recent years. Neukölln's cultural infrastructure - in the narrower sense - is made up by the Gallery at Saalbau, the stage Home Port, Neukölln Opera, Puppet Theatre Museum, Neukölln Museum, Community House Gropiusstadt, etc. The association Culture Network Neukölln brings together all these venues and promotes their work. The district's flagship project is the art festival 48 Hours Neukölln which takes place every June. Cultural initiatives like those mentioned above have definitively managed to enhance the quality of living in Neukölln and to improve the district's image (R. Kramer, personal communication, April 10, 2013, B. Müller personal communication, April 11, 2013).

The district Ménilmontant in the east of the French capital has a rich cultural scene of longstanding and recent cultural facilities and institutions to offer. Among those are public theatres like Théâtre de la Colline and Le Tarmac as well as private theatres such as Théâtre de Ménilmontant, Les Rendez-Vous d'Ailleurs and Théâtre de l'Ogresse. La Maroquinerie and La Flèche d'Or are famous music venues. Furthermore, some medium-sized and smaller music locations like Studio de l'Ermitage, Café des Sports or Bar 96 exist. La Bellevilloise, Lieu-Dit, Lou Pascalou and Trois Arts present various arts. Many galleries are grouped together in the northwest of the district. The multiplex cinema MK2 Gambetta is situated near the district municipality. In recent years, the Paris municipality established three new cultural institutions: The district cultural centre Carré de Baudouin, the Médiathèque Marguerite Duras and the House of Amateur Arts. The new multiplex cinema Étoile Lilas is located in the northeast of Ménilmontant. Some cultural facilities such as Comédie de la Passarelle and Z'Indems Café have been forced to close, or like district theatre Vingtième Théâtre - are currently in a state of crisis. Notwithstanding, the $20^{\text {th }}$ district of Paris shows very positive developments. The cultural scene remains vibrant and the recent cultural venues have 
especially led to an improvement in living conditions and resulted in an upgrading of the area. Moreover, the Paris municipality has refurbished the Saint-Blaise quarter in the east of the district and a new tramway line T3 at the district's eastern border has been put into operation (Marie du 20 ième arrondissement de Paris 2016, Rohn 2013, 2014).

Regarding cultural development, the district Ottakring in the west of the Austrian capital is number one among Vienna's outskirt areas. Being a traditionally working class living area and later characterised by a high proportion of migrants, Ottakring's image has been successfully converted into that of a cultural district offering a quite pleasant quality of living. The cultural facilities established in the district by artists and residents took a leading role in this transformation process. Starting with the art-fair Soho in Ottakring, a broad range of cultural facilities came into being since the end of the 1990s. Among those are the gallery MASC Foundation, the association Grundstein representing cultural facilities located at Grundsteingasse, the intercultural venue Brunnenpassage, the music venues The Loft and Café Concerto and many more. The success of Ottakring's cultural development has already spread to neighbouring districts along the Westgürtel (Rohn 2013, 2015).

Novi Zagreb, the southern part of the Croatian capital, is basically an area dominated by prefabricated housing estates, made up of the New Zagreb-East and New Zagreb-West districts. During the last decade or so, Novi Zagreb has been upgraded by cultural institutions like the above-mentioned Museum of Contemporary Art Zagreb, the two multiplex cinemas Cinestar Novi Zagreb and Cinestar Arena IMAX and the sports facility Arena Centre, which also holds concerts. Two district cultural centres, namely the International Centre for Cultural Services in New Zagreb-East and the cultural centre in New Zagreb-West, were established earlier than the facilities listed above. Furthermore, Novi Zagreb houses the Zagreb Fair and the annual music festival Bundek, the latter near to the Museum of Contemporary Art Zagreb. Overall, New Zagreb shows very positive developments with the recent cultural facilities helping democratise culture, generating new jobs and enhancing the quality of living in the area (Grad Zagreb 2016, Rohn 2014, Zagreb Tourist Board 2016).

Although not every positive development in the case study districts depicted above can be attributed to efforts in the field of arts and culture, the cultural facilities and institutions are definitively generating valuable effects.

\section{Comparison of the Four Cities' Cultural Policies}

As key players in cultural policy, the state and the municipality are of varying importance in each of the four cities. When looking at the significance of the respective districts, Berlin ranks first followed in by Paris, Vienna and Zagreb. Whereas in the German capital the districts play an important role, it is slightly less pronounced in Paris and even less in Vienna. In Zagreb the districts fulfil only minor functions. 
For various reasons the cultural budgets of the four metropolises are not comparable: The relevance of the state as a player of cultural policy in the cities varies and there are different tasks for each municipality and diverging structures for the cultural budgets.

In all four cities, quite a number of the large cultural institutions like theatres, opera houses, concert halls or museums - financed either by the state or by the municipality - are located in the city centre. Nevertheless, there are different approaches to and degrees of decentralisation when it comes to cultural facilities in the four cities: Paris and Zagreb are following a top-down approach. The central municipalities have created many cultural institutions on the outskirts of their cities. In contrast, Berlin utilises a bottom-up approach. New cultural facilities are created by artists or local residents. Vienna uses a kind of combined strategy where some cultural institutions are being developed by the municipality. Nevertheless, the majority of new cultural facilities are created independently by activists. Only when they get bigger do the cultural facilities become eligible for funding by the Vienna municipality.

As shown in the city profiles above, Paris and Zagreb enjoy a higher degree of decentralisation of cultural facilities than the two other cities. Recent cultural flagship projects on the outskirts of Paris are, for example, the City of Fashion and Design, the Institute for Islamic Culture and the fine arts centre Centquatre (104). Zagreb's outstanding project on the city's fringes is the Museum of Contemporary Art. Berlin has no cultural flagship projects on the outskirts at present. As shown in the previous section, Vienna's more recent bigger projects on the outskirts are primarily event locations and educational institutions.

In terms of best practice, examples can be offered from each of the four cities. In Berlin, the Atelier programme for artists is highly recommendable. With programmes like Aktionsräume ${ }^{\text {plus }}$ and Quartiersmanagement the Berlin municipality successfully created links between urban regeneration and social affairs agendas with those for culture. The decentralisation of tasks in the field of culture produces closer contacts between the administration and citizens.

The Paris municipality provides its districts with a budget of one euro per inhabitant for local cultural programmes. Specific programmes for cultural policy in favour of the outskirts are the Charter of Cultural Cooperation (2009) and Paris, City of Culture and Creation (2011).

For cultural facilities in the urban periphery, Vienna has a combination of top-down and bottom-up approaches. As in Zagreb, the Austrian capital has a rich culture of festivals.

The local cultural centres and the programme City Acupuncture show the definitive advantages of Zagreb's policy in the field of culture and urban regeneration.

Administrative versus spatial decentralisation is another perspective through which to analyse the four municipalities' policies. Administrative decentralisation is characterised by decision-making powers and the financial resources being (more or less) transferred to a subordinate body, as is the case with Berlin's districts. In the best-case scenario, this is accompanied by a 
spatial decentralisation of, let's say, cultural facilities. In contrast, spatial decentralisation means that the central municipality keeps all decision-making power and develops cultural facilities on the outskirts by itself. This is the case in Paris and Zagreb and partly the case in Vienna.

Different strategies can be identified in the four municipalities concerning the regeneration of fringe areas too. Paris and Zagreb have sought to favour disadvantaged areas through cultural means. By contrast, the Berlin municipality does not use cultural resources as means of urban regeneration. In the German capital, the development of peripheral areas is primarily a matter of urban regeneration. Vienna is also more on the urban regeneration side.

In following an explicit strategy in favour of its peripheral districts, Paris is in a singular position. Zagreb develops projects on the city's outskirts in a more informal way, but is willing to strengthen its efforts in the course of its Cultural Strategy 2014-20. The municipalities of Berlin and Vienna have not yet formulated cultural policies in favour of their fringe areas.

\section{Conclusion}

In the previous sections, various approaches to culture in the urban peripheries and different conceptions of a cultural policy towards the outskirts have been described and analysed. Ironically, municipalities in more centralist states like Paris and Zagreb - when it comes to culture - are doing more for their peripheries than those in states with a federal structure, that is to say Berlin and Vienna.

So, what could be further done in the four case study cities? According to the basic requirements of a cultural policy in favour of the outskirts demonstrated in the section Research Work, the author would like to propose the following: The municipalities of Paris and Zagreb - both generally doing well in their respective cultural policies - should move to decentralise decision-making power and financial resources and proceed from a spatial to an administrative decentralisation. Berlin is doing well in terms of administrative decentralisation and should provide its districts with proper financial means to fulfil their tasks in the field of culture. Finally, Berlin and Vienna might be well advised to aim for a spatial decentralisation of major cultural institutions.

The improvement of cultural infrastructure on the outskirts of a city is a fundamental contribution to the improvement of living conditions and represents an important question of participation and democracy. For most municipalities there is still room and opportunity for improvement.

\section{Acknowledgment}


The author wishes to express his thanks to two anonymous referees for their valuable comments and recommendations and, in particular, to Jennifer Carvill Schellenbacher for her engaged work on language editing. 


\section{References}

Bianchini F, Ghilardi L (2004) The Culture of Neighbourhoods: A European Perspective. In D Bell, M Jayne (Eds) City of Quarters: Urban Villages in the Contemporary City, 237-248. Aldershot: Ashgate.

Büchereien Wien (2016) Geschichte. Kurze Geschichte des Wiener öffentlichen Bibliothekswesens [History. Short history of public libraries in Vienna]. Retrieved from http://bit.ly/2bTlCyi.

Bundeskanzleramt (2016) Adressen und Links Bundesmuseen [Adresses of and Links to State Museums]. Retrieved from http://bit.ly/2cvGFFz.

Bundestheater (2016) Bundestheater.at [State Theatres.at]. Retrieved from http://bit.ly/2cCVYNX.

Centrikulture (2016) Zagrebacki centri za kulturu [Cultural Centres in Zagreb]. Retrieved from http://bit.ly/2cgbCx8.

Cinémathèque française (2016) La Cinémathèque française [The French Cinema Museum]. Retrieved from http://bit.ly/1cbilyP

Connaissance des Arts (1989) Grands travaux. Connaissance des Arts, numéro special [Great Works, Special Issue of Knowlegde of Art]. Paris: Société Française de Promotion Artistique.

Der Regierende Bürgermeister von Berlin - Senatskanzlei Kulturelle Angelegenheiten (2011) Kulturförderbericht 2011 des Landes Berlin [Report on Cultural Funding by Berlin County 2011]. Retrieved from http://bit.ly/1WZvSkZ.

Der Regierende Bürgermeister von Berlin - Senatskanzlei Kulturelle Angelegenheiten (2015) Kulturförderbericht 2014 des Landes Berlin [Report on Cultural Funding by Berlin County 2014]. Retrieved from http://bit.ly/1WZvSkZ.

Florida R (2013) The Most Famous Models for How Cities Grow Are Wrong. We need new ways to explain growing urban inequality. Atlantic City Lab, 9/8/2013. Retrieved from http://bit.ly/2c3KWw7.

Geschäftsgruppe Kultur und Wissenschaft des Magistrats der Stadt Wien (2015) Kunst- und Kulturbericht und Frauenkulturbericht der Stadt Wien 2014 [Report on Arts and Culture and on Women in the Arts by the Vienna Municipality 2014]. Vienna. Retrieved from http://bit.ly/2bPzRxU.

Grad Zagreb (Ed) (2016) Službene stranice Grada Zagreba [Official Website of the City of Zagreb]. Retrieved from http://bit.ly/2ckjTOL.

Gréco B (2012) Delanoë, adjoint de lui-même à la culture ? [Delanoë, his Own Successor as Councilor for Culture?]. Journal du Dimanche 1/7/12. Retrieved from http://bit.ly/2c8Uk4p.

Heineberg H (2000) Grundriss allgemeine Geographie: Stadtgeographie [Compendium of General Geography: Urban Geography]. Paderborn, München, Wien, Zürich: Schöningh.

Institut des Cultures d'Islam (2016) Institut des cultures d'Islam [Institute of Islamic Cultures]. Retrieved from http://bit.ly/2coy5oW.

Latour B (2007) Eine neue Soziologie für eine neue Gesellschaft. Einführung in die Akteur-Netzwerk-Theorie [A New Sociology for a New Society. Introduction to actor-network-theory]. Frankfurt am Main: Suhrkamp.

Magistrat der Stadt Wien (2015) Wien in Zahlen 2015 [Vienna in Numbers 2015]. MA 23 - Wirtschaft, Arbeit und Statistik. Wien. Retrieved from http://bit.ly/2c09qrd.

Mairie de Paris (2009) Charte de coopération culturelle 2009-2011 [Charta of Cultural Cooperation 2009-2011]. Retrieved from http://bit.ly/2cgbw8w. [ Accessed 8 November 2012]. 
Mairie de Paris (2011) Politique culturelle de la ville de Paris [The Paris Municipality's Cultural Policy]. Paris: Mairie de Paris.

Mairie de Paris (2012a) Key figures for Paris. Retrieved from http://bit.ly/2bUhriS. [Accessed 8 November 2012].

Mairie de Paris (2012b) Présentation de la direction [Presentation of the Directorate]. Retrieved from http://bit.ly/2c7nKz8. [Accessed 8 November 2012].

Mairie de Paris (2012c) Rapport d'activité 2011 de la Direction des Affaires Culturelles [Report on Activities by the Directorate of Cultural Affairs in 2011]. Retrieved from http://bit.ly/2ccsvtR. [Accessed 8 November 2012].

Mairie de Paris (2013) Chartre de coopération culturelle 2013-2015 [Charta of Cultural Cooperation 2013-2015]. Retrieved from http://bit.ly/2cD10Kh.

Mairie de Paris (2016) Le budget primitif 2016. Rapport budgetaire [Provisional budget for 2016. Report on the budget]. Paris: Direction des Finances et des Achats. Retrieved from http://bit.ly/2bQ5bkI.

Marie du $20^{\text {ieme }}$ arrondissement de Paris (2016) Mairie Paris 20 [Municipality of the $20^{\text {th }}$ District of Paris]. Retrieved from http://bit.ly/2cg52GZ.

Metzger R (2015) Die Stadt. Vom antiken Athen bis zu den Megacities. Eine Weltgeschichte in Geschichten [The city. from ancient athens to the megacities. a history of the world in stories]. Vienna: Brandstätter.

Mulcahy KV (2006) Cultural Policy: Definitions and Theoretical Approaches. In Educult ICCPR 2006/ Proceedings/ CD-Rom. Fourth International Conference on Cultural Policy Research, University of Music and Performing Arts. Vienna, $12-16 / 7 / 2006$.

Pavillon de l'Arsenal (2009) Paris en chiffres [Paris in Numbers]. Paris : Pavillon de l'Arsenal.

Philharmonie de Paris (2016) Philharmonie de Paris [Paris Philharmony]. Retrieved from http://bit.ly/1LDuFrW.

Rohn W (2013) Die neue Kultur am Rand der Städte: Wien und Paris [New Culture on the Outskirts of Cities: Vienna and Paris]. Vienna: Praesens.

Rohn W (2014) Bericht zum vierten Teil des Forschungsprojekts neue Kulturinitiativen als Motoren für die Entwicklung peripherer Stadtteile [Report on the Fourth Part of the Research Project New Cultural Facilities as Engines for the Development of Urban Fringe Areas]. Vienna: Institut für Stadt- und Regionalforschung der ÖAW.

Rohn W (2015) Wien als dezentrale Kulturstadt der Zukunft [Vienna as a Future Decentral Cultural City]. In J Fritz, N Tomaschek (Eds) Die Stadt der Zukunft. Aktuelle Trends und zukünftige Herausforderungen [The City of the Future. Current trends and future challenges]. University - Society - Industry 4, 253265. Münster/New York: Waxmann.

Schaper R (2014) Berlins neuer Kulturstaatssekretär Tim Renner - eine absichtsvolle Fehlbesetzung [Tim Renner, Berlin's New Councillor for Culture - a Deliberate Miscast?]. Der Tagesspiegel, 27/2/2014. Retrieved from http://bit.ly/2bQck4I.

Senghaas D (Ed) (1972) Imperialismus und strukturelle Gewalt. Analysen über abhängige Reproduktion [Imperialism and Structural Violence. Studies on dependent reproduction]. Frankfurt am Main: Suhrkamp.

Senghaas D (Ed) (1974) Peripherer Kapitalismus. Analysen über Abhängigkeit und Entwicklung [Peripheral Capitalism. Studies on dependency and development]. Frankfurt am Main: Suhrkamp.

Skot-Hansen D (2005) Why Urban Cultural Policies? In: J Robinson (Ed) Eurocult 21. Integrated Report. Eurocult 21. Helsinki, 31-39. Retrieved from http://bit.ly/ 2bPw2ZH. [Accessed 3 September 2009]. 
Soho in Ottakring (n.d.). Soho in Ottakring [Soho at Ottakring]. Retrieved from Retrieved from http://bit.ly/2bPzMtT.

Stadt Wien (2016) Bildungszentrum Simmering - Planung [Education Centre Simmering - Planning]. Retrieved from http://bit.ly/1ByGYTM.

The World Bank (2016) 2016 World Development Indicators. International Bank for Reconstruction and Development/The World Bank: Washington DC. Retrieved from http://bit.ly/1T5THUv.

Trsat Polo d.o.o. (n.d.) Zagreb Plan Grada/ City Map 1:20.000. Zagreb.

Vereinigte Bühnen Wien (2016) Raimund Theater, Ronacher, Theater an der Wien [Raimund theatre, Ronacher, theatre at River Vienna]. Retrieved from http://bit.ly/2c94su0.

Vienna Design Week (Ed) (2016) Vienna Design Week 25 September - 4 October 2015. http://www.viennadesignweek.at/archive.php.

Wikipedia (2016a) Berlin. Retrieved from http://bit.ly/1LYE2IN.

Wikipedia (2016b) Paris. Retrieved from http://bit.ly/115BSex.

Wikipedia (2016c) Wien. Retrieved from http://bit.ly/2c3UTtw.

Wikipedia (2016d) Zagreb. Retrieved from http://bit.ly/2cD1znu.

Wikipedia (2016e) Bertrand Delanö̈. Retrieved from http://bit.ly/2cD1D6B.

Wikipedia (2016f) Anne Hidalgo. Retrieved from http://bit.ly/2c3UG9N.

Wikipedia (2016g) Milan Bandić. Retrieved from http://bit.ly/2bUjcwe.

Zagreb Tourist Board (2016) InfoZagreb.hr. Retrieved from http://bit.ly/2a6txkJ. 
